\title{
The Socio-Economic Background of Khasia Ethnic Community of Bangladesh
}

\author{
Md.Kayum Shikdar ${ }^{1}$, Amitkumar Biswas ${ }^{2}$, Ripon Mollick ${ }^{3}$ \\ 1,2,3(Under Graduate Student of Sociology Discipline, Khulna University, Khulna-9208, Bangladesh.)
}

\begin{abstract}
Different ethnic groups of Bangladesh and their colorful lifestyles have significantly enriched the entire culture of Bangladesh. For centuries, Bangladesh has been the dwelling place of different ethnic groups. At least 350 million people worldwide are considered to be indigenous and in Bangladesh about two million indigenous people of 45 different distinct communities are living throughout the country (Hossain, 2003). These people with distinctive social and cultural practices, languages and customs are commonly known as 'Adivasis' by themselves. Among them Khasis are one of the most disadvantaged and vulnerableAdivasi community living in Sylhet and Moulvibazar districts. They have been characterized by the dominant groups as distinctive with their comparatively more isolated habitation in the hilly and forest areas and their distinct socio-economic and cultural lives ( Munda,2002). TheKhasiMongolite ethnic group. The Khasia's descended to the Khasia hills and Jaintia hills from Cherapunji and Shilong regions. They migrated to Bangladesh from Assam where they came about five hundred years ago, presumably from Tibet, and now form one of the major matriarchal tribes in Bangladesh. Khasias are short people with flat noses and mouths, high jaws, and small and straightened black eyes. This matrilineal ethnic group resides mainly in 11 Upazilas of the greater Sylhet District in the Northeastern region of Bangladesh. According to the government census of 1991, the Khasi population in Bangladesh is 12,280. Their livelihood pattern and their culture are different from the mainstream population. Khasia peoples play a great role in our socio economic condition. They are part and parcel of our tradition. They have to face a number of problems in their daily life. To alleviate their problems we should co-operate them.
\end{abstract}

Keywords -Khasi, Socio-economic, Modernization, Karitas, matriarchal.

$\begin{array}{ll}\text { ACRONYMS } & \\ \text { ILO } & \text { International Labor Organization } \\ \text { UN } & \text { United Nation } \\ \text { GO } & \text { Government Organization } \\ \text { NGO } & \text { Non-Government Organization }\end{array}$

\section{GLOSSARY}

Chang Gor

Dhara and khatokkarcha

Dorbar

Jaminder

Khasi

malaishito

Murabbi

Punji

RangbahShnong

\begin{abstract}
Khaca house in which they dwell.
Very costly dress of Khasia female.

General council

Head man of the Khasia community.

Mongo lite ethnic group of Bangladesh.

A game of hitting a piece of stick

Honorable person of Khasia community.

Community ofKhasia

Village elder
\end{abstract}

\subsection{Statement of the problem}

\section{Introduction}

Khasia is one of the ethnic groups of Bangladesh. Earlier, Khasia people used to live along the northeast border of Sunamganj district. At present they are spread over Bishwamvarpur, Tahirpur and Chhatak in Sunamganj. Most Khasias live in the border region. Many Khasia children are found working in the tea gardens in Kulaura.

According to the census in 1991, the total number of Khasias in Bangladesh was 12,280; but the Bangladesh Khasia Society claims the number to be around 30,000. In fact, the birth rate is very high among the Khasias. Khasias are short people with flat noses, high jaws and small slanting black eyes. They are fond of hills, mounds, bushes and forests. 
The conditions of Khasia peoples in our country are very poor. They have their own socio cultural traditions. They migrated to Bangladesh from Assam where they came about five hundred years ago, presumably from Tibet, and now form one of the major matriarchal tribes in Bangladesh. Khasias are short people with flat noses and mouths, high jaws, and small and straightened black eyes.

This report is made with the information of 3 different households. Here I found the condition of the small ethnic groups' peoples.

\subsection{Objectives of the study}

The following objectives are laid for the study:

1. To know the origin and development of Khasiacommunity.

2. To know about their living standard.

3. To know about their colorful lifestyle.

4. To know the women status of Khasiacommunity.

5. To know their marriage system

6. To know about their socio-economic condition.

7. To compare the livelihood pattern of majority people and minority people.

8. To know the impact of modernization and other socio cultural changes.

9. To know the problems of minority people.

10. To find out the solution of the problems.

\subsection{Limitation of the Study}

There are some limitations to prepare this report. Those are

1. While we went to collect data from the respondents they were very busy.

2. There was a language or communication gap.

3. Lack of time to conduct with Khasia ethnic people.

4. Sometimes they filled with fear.

5. Respondents can't answer properly to my questions.

6. They felt bored. Because various GOs \& NGOs fieldworkers often visit their community.

7. Lack of time to prepare this report.

8. Lack of financial support.

\subsection{Study Design}

\section{Methodology}

Case study and participant observation method was taken to conduct this study. The main purpose of our study is to explore the socio-cultural condition of the Khasiacommunity. Both primary and secondary data were used in conducting this study. To collect primary data 3 case study were conducted among the Khasiacommunity. Secondary data are collected through different reports of web materials, various articles, journals and books. The whole study design was prepared in following way-

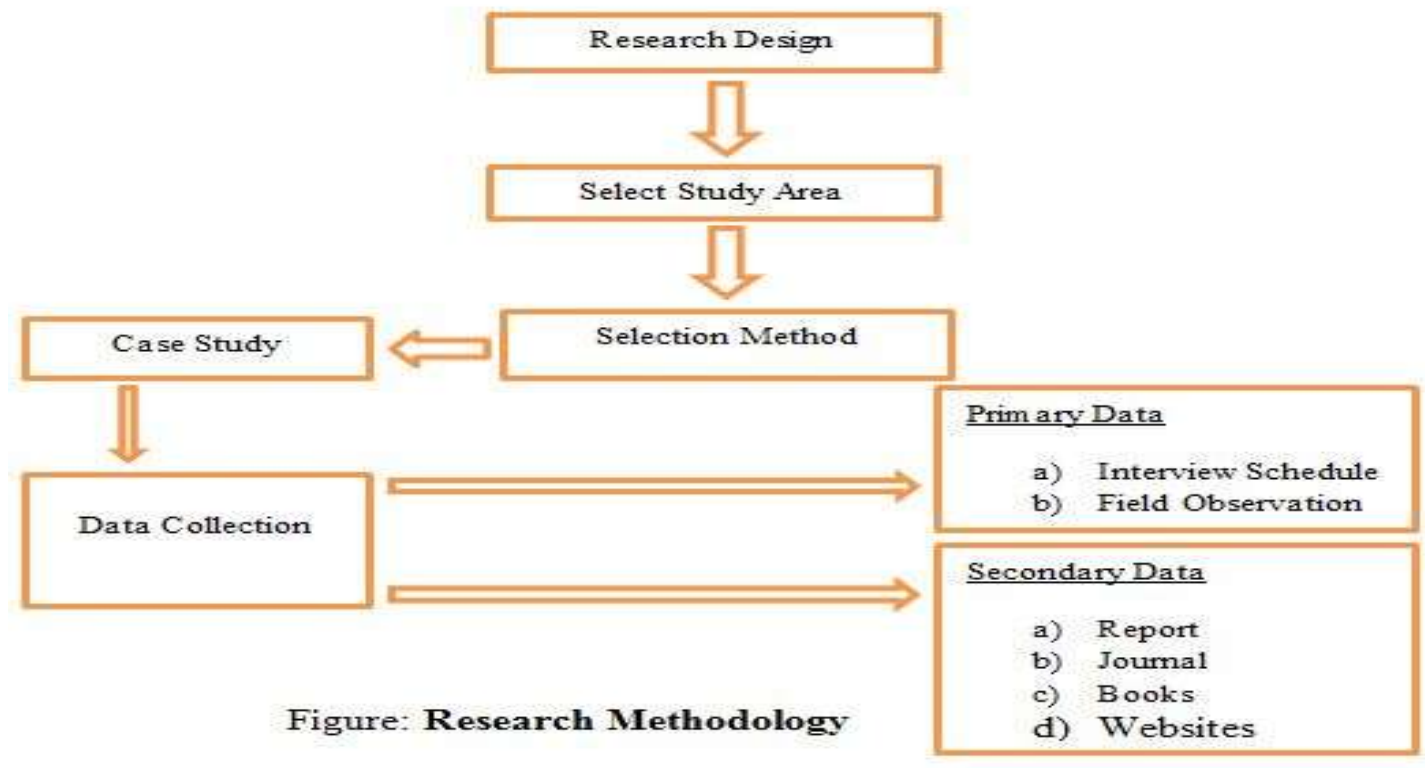




\subsection{Study area}

The study area is at SongramPunjiatGowainghatupzilla in Sylhet District. The flowing map covers study area with yellow color.

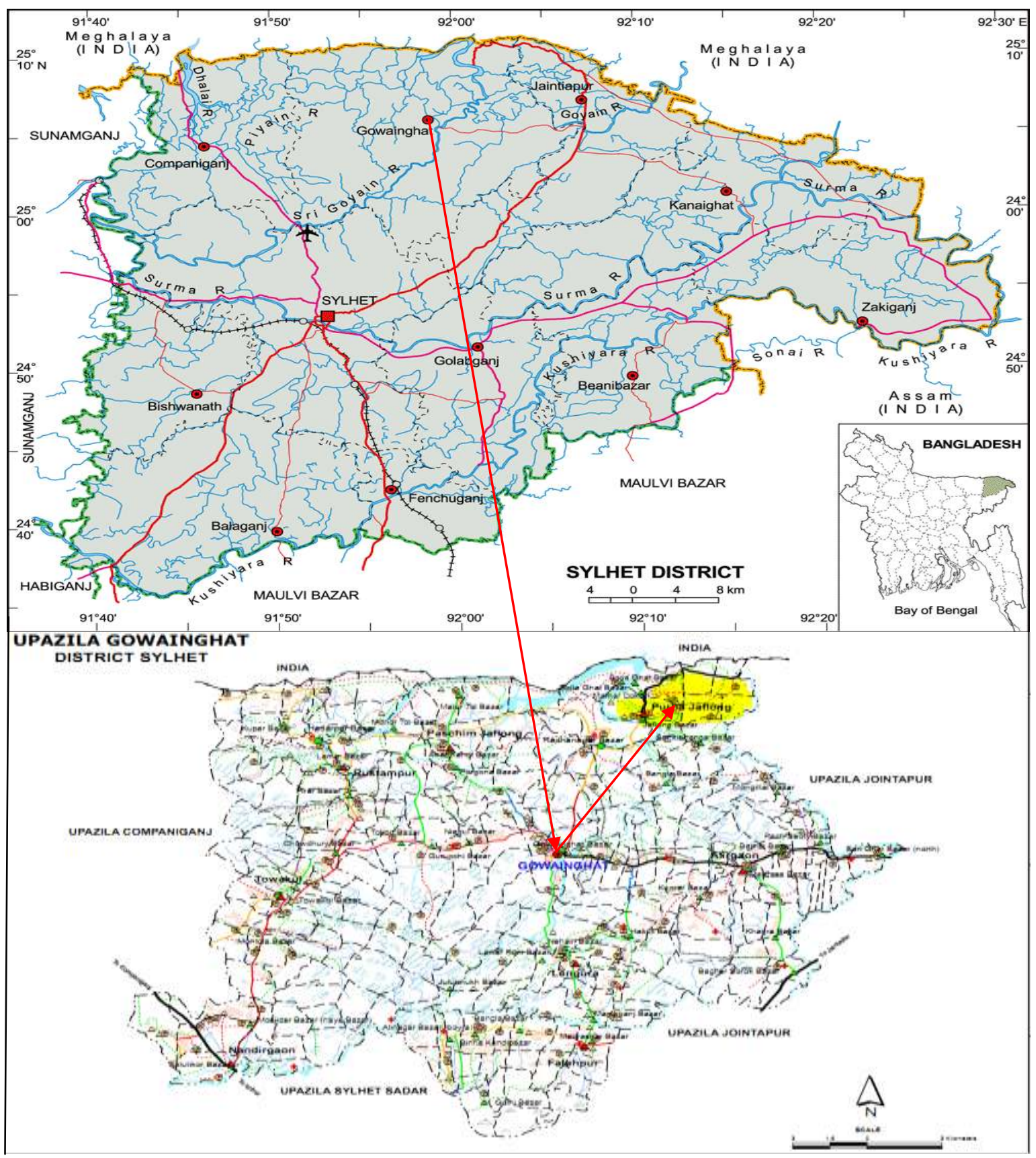

\subsection{Some observations about the study area}

- The socio economic condition is not so good.

- Most of people of this area involved in agriculture specially betel leaf and betel nut cultivation.

- Crops and trees damage by the mainstream people.

- The education level of the minority people is quite low.

- Most of the houses of this area are made by brick and some are wood and bamboo made.

- Sanitation system is nice in this area.

- The people of this area are very conscious about their children education.

- The medical facilities are not sufficient in this area.

- They drink deep Tube-well water. 
The following page I try to explain the livelihood pattern and the socio economic condition of the Khasia people:

\subsection{Introduction}

\section{Body of The Report}

The Khasi tribe, which lives in India and Bangladesh, is known for its matrilineal culture in which women dominate a family. As the economy develops, the life of Khasi is improving. There are more than one million Khasi people in India and around 30,000 in Bangladesh, mainly in northeastern Sylhet Division. Before partition of India and Pakistan in 1947, Khasi people belonged to one country. After partition, majority of Khasi live in India, and the rest in Bangladesh.Khasi people still preserve the tradition that women inherit their ancestor's property, such as land. Monogamy marriage system is strictly flowed in kashia community. According to the tradition, the groom has to live in the bride's house after getting married, but now fewer men does so.

\subsection{Origin and History of Khasia}

The origin of the Khasi is a very vexed question. Although it is probable that the Khasis have inhabited their present abode for at any rate of considerable period, there seems to be a fairly general believes amongst them that they originally come from elsewhere (Gurdon -1996). Their history of migration is still under mystery and based on affinities with other ethnic people and their migration history. Many ethnologists mentioned that the Khasis originally came into Assam from Burma.

Referring Aymonier, Gurdon (1996) notice that the Khasis are connected with people who inhabited the Malay Peninsula and Chota Nagpur at the time of the stone age. Dutta (1982) describe the Khasis as Pale Mongoloid people who speak an Austric tongue, Mou Khmer which they were believed to have adopted in course of their wandering long before they settled in their present habitat.

Historical evidences suggest that the Austric speaking race the Mons started to rule Burma in 11th century and continue it for few centuries. This race practiced matrilineal system and it is assumed that they were the ancestor of modem Khasis people (Barch, 1974). Defeated by Burmese the Mons shifted their habitat to Assam. Historical background suggests that Mon-Khmer speech has age-old civilization in Vietnam. Beside Khmer in Cambodia, the Khasi megalithic culture are connected with the Mon-Khmer groups of Laos, Thailand, Indo-China, Indonesia and Malaysia (Barch, 1974). Side by side Khasi-Jaintia was a MonKhmer speech located in Meghalaya from time immemorial. Focusing the given historical facts Gurdon (1996) concluded that the Khasis are an offshoot of the Mon people. Considering very close connection with the language and culture of Mon-Khmer group Chowdhury (1998) has described the Khasis as immediate connected people with the Mon, Palaung and War of Burma. He also mentioned that the Khasis in Assam of British India was the only member of Mon- Khmer Group who have migrated from Burma. However, few ethnologists observed some likeness between the Khasis, Synthengs and Nagas. They understood that the forefather of the Khasis in the course of migration in to their present settlement possibly passed through the country of Nagas and few Naga Customs has transmitted in to the Khasi customs or vice versa.

Due to lack of available literatures and historical evidences, until now the history of origin of the Khasis is mainly based on assumption and myths. The Khasis have not apparently preserved any tradition as to the direction their forefather had come from (Chowdhury, 1998) and very specific and authentic ethnic history of this people is yet to be established. Considering different research scholars and ethnologists literatures the Khasis may be introduced as an offshoot of Mon-Khmer people with Austric language.

\subsection{Migration and Settlement in Sylhet}

The exact time and event of migration of the Khasis in Sylhet is still under mystery. Khasi people believe that they were planted by the God in the beginning of time (Chowdhury, 1984). According to Gurdon (1996) Khasis settled in Jaintapur migrated from Assam in sixteen century. At that time they had established an independent Kingdom at Jaintapur which was located in Sylhet district.

However, the accurate time of the formation of KhasiJaintia Kingdom is still an unsolved matter in the history. Few ethnologists mentioned that Jaintia Kingdom was established in 1500 A.D. This Kingdom captured the areas of present Sylhet, Sunamgonj, parts of Moulavibazar and Hobigonj districts (Rahman, 2004). After 1835 the Khasi Kingdom was occupied by the British. In courses of time many of the Khasis shifted their habitat into different hilly forest areas of Sylhet division and now their major concentration is in KulauraUpazilla of Moulavibazar districts. Due to lack of available statistics, it is difficult to figure out their actual number, number of villages where the live etc. It is assumed that

Bangladesh has about 90 (ninety) Khasi villages with an approximate twenty thousand of population (Rahman, 2004). Their habitats are mainly in deep hilly forestlands. Few also live in the plain land of 
Sylhet district. Rahman (2004) collected the name of 71KhasiPunjis. Among those 5 and 3 is in Goainghat and JaintapurUpazilla of Sylhet district respectively; 38, 11, 07 and 04 is in Kulaura, Barolekha, Sreemangal and KamolgonjUpazilla of Moulavibazar district respectively; Bahubal and Chunarughat, each of this two Upazillas have one punji and TaherpurUpazilla of Sunamgonj district has one punji.

\begin{tabular}{|c|c|c|}
\hline Districts & Upazilla & Number of Punji \\
\hline \multirow{3}{*}{ Sylhet } & Goainghat & 05 \\
\cline { 2 - 3 } & Jaintapur & 03 \\
\hline \multirow{3}{*}{ Moulavibazar } & Kualura & 38 \\
\cline { 2 - 3 } & Barolekha & 11 \\
\cline { 2 - 3 } & Sreemangal & 07 \\
\cline { 2 - 3 } & Kamolgonj & 04 \\
\hline Sunamgonj & Taherpur & 01 \\
\hline Hobigonj & Bahubal & 01 \\
\cline { 2 - 3 } & Chunarughat & 01 \\
\hline
\end{tabular}

\subsection{Geographical Distribution and Sub-Groups of Khasia}

The total Khasi population may be estimated at 1.2 million people. According to the 2001 Census of India over 1.1 million Khasi lived in Meghalaya, in the districts of East Khasi Hills, West Khasi Hills, Ri-Bhoi and Jaintia Hills. In Assam their population reached 13,000. The Census of Bangladesh ennumerated 12,280 Khasi for the whole country in 1991. It is generally considered that the Khasis consist of four sub-tribes: Khynriam, Pnar, Bhoi and War. The Khynriam inhabit the uplands of the Khasi Hills District, the Pnar or Syntengs live in the Jaintia Hills. The Bhoi live in the lower hills to the north and north-east of the Khasi Hills and Jaintia Hills towards the Brahmaputra valley. The War, usually divided into War-Jaintia, in the south of the Jaintia Hills and War-Khasi in the south of the Khasi Hills, live on the steep southern slopes leading to Bangladesh. The Lyngngam people who inhabit the western parts of the Khasi Hills display linguistic and cultural characteristics which show influences from both the Khasis to their east and the Garo people to the west

\subsection{Genetics}

Khasi people from different regions have small, but noted differences. Recent genetic researches have shown that Khasis are closer to their Garo neighbors as compared to other populations of Northeast India. Physical appearance of many Khasis include earthy complexions through to Anglo and other Eurasian influenced ones. They do not possess the stereotypical mainland Indian features and may even drift towards other central Asian ones (Kazakhstan, Kyrgyztan). The features may be described as East Indian or north-east Indian. However, the variations remain high.

\subsection{Physical Structure}

Khasias are migrated to Bangladesh from Assam where they came about five hundred years ago, presumably from Tibet, and now form one of the major matriarchal tribes in Bangladesh. Khasias are short people with flat noses and mouths, high jaws, and small and straightened black eyes.

\subsection{Language}

In the past, the Khasi language had no script of its own. William Carey attempted to write the language with the Assamese script between 1813 and 1838. A large number of Khasi books were written in the Assamese script, including the famous book KaNiyiom Jong KaKhasi or The Rule of the Khasis, which is an important manuscript of the Khasi religion. The Welsh missionary, Thomas Jones, in 1841 wrote the language in the Latin script. As a result, the Latin alphabet of the language has a few similarities with the Welsh alphabet.

- Capital letters A, B, K, D, E, G, Ng, H, I, İ, J, L, M, N, Ñ, O, P, R, S, T, U, W, Y.

- Small letters a, b, k, d, e, g, ng, h, i, i, j, l, m, n, ñ, o, p, r, s, t, u, w, y,

Khasi people has their own language which was invented by American missionary in the 19th century, But they are not using it now. In local schools, only Bengali and English are taught.

\subsection{Marriage and residence pattern}

Marriage is a purely civil contract. Males are between the ages of 18 and 35 when they marry, while women's ages range from 13 to 18. Although parentally arranged marriages do occur, this does not appear to be the preferred form. Young men and women are permitted considerable freedom in the choice of mates and in premarital Sexual relations. According to Khasi laws, a woman cannot be forced into marriage, she owns the children and properties. A woman may end a marriage at her will with no objection from her husband. Monogamy marriage system is strictly flowed in kashia community. According to the tradition, the groom has to 
live in the bride's house after getting married, but now fewer men does so. Their families are monogamy and they are matrilocal. There is no scope of dowry or mohoror any other give and take system in their marriages.

\subsection{Socialization Pattern of Khasia}

Naming occurs one day after birth. Family activities center on the performance of religious rites, management of family property, and the maintenance and protection of kin relations. Men, women, and children participate fully in these and other labor-related activities. Women, however, are the chief agents of socialization.

\subsection{Inheritance}

The most remarkable social institution of the Khasis is the system of matrilinealism. Except among the Garos; it does not appear among any other races and tribes in Bangladesh. A characteristic feature of the Khasimatriliinealism is the succession of the youngest daughter calledKaKhudduh in Khasi language to the property of the family (Dutta, 1982). Although other sisters might be allowed to share of the common inheritance, but the largest portion in variably fell to the youngest and brothers are excluded from all shares of the ancestral property. Property ownership custom is treated as achieved by own earning for the male members of the Khasi community. Therefore, youngest daughter is seems to 'be powerful in the context of property inheritance. As youngest daughter share a major portion of the inheritance property, she has to perform some responsibility i.e. She is expected to observe the traditional family rites and ceremonies; she has to take care of her older parents, bear the responsibilities of unmarried brother and sisters or any dependent relatives living her mother's home along with husband and children (Barch, 1974).In the event there is a single daughter, she will get the entire property. If there be no daughter, the ancestral residence and property goes to the elder sister's lineage.

\subsection{Education}

Education is low among Khasi community where education of children rarely progresses past primary level. There are no secondary schools located nearby. The flowing picture showing a primary School of my study area at SangramPunji named SangramPunji primary School.

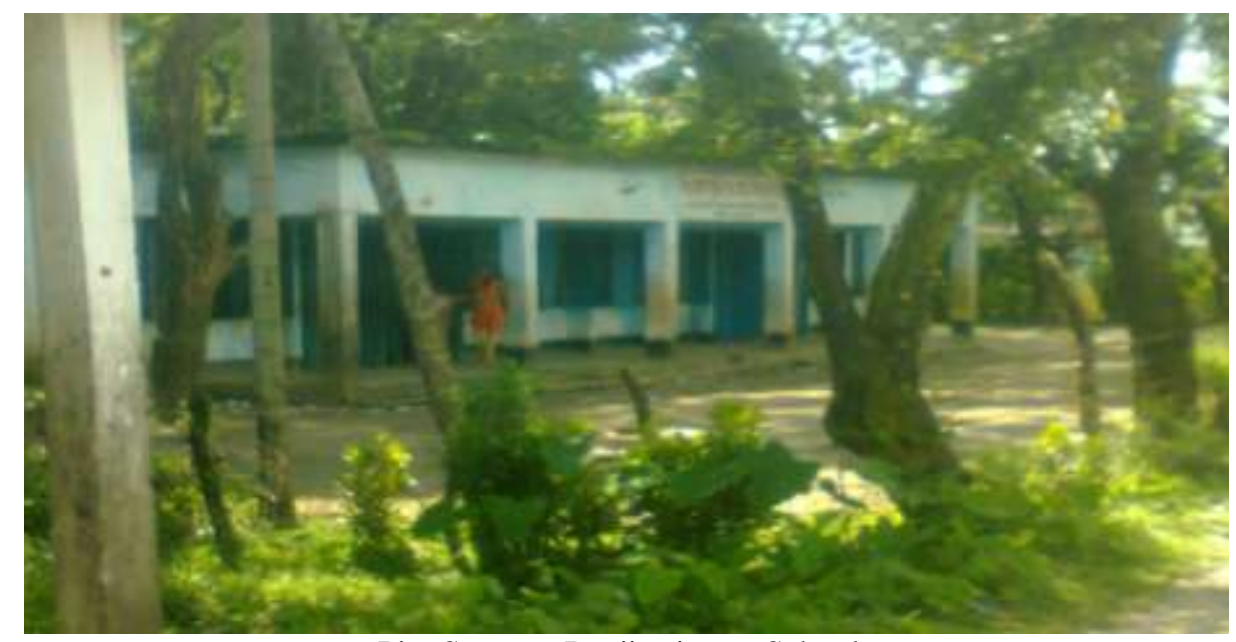

Pic: SangramPunji primary School.

Language also creates a problem as many lessons are conducted in Bangla and not the mother language. Rich Khasi people send their children to study various recognized collage, and university in the country as well as in India or western countries.

\subsection{Occupation of Khasia}

Khasis occupation is called as JHUM Means shifting cultivation for their survival. They have a peasant based economy. There are more than 100 Khasi villages in Sylhet Division. The Khasi people mainly do farming, grow betel palm and do other business.

Agnes Dikhar was one of my responders said like other Bangladeshis, Khasi men now look after business and women look after family affairs. Khasi people peacefully co-exist with Bengalis and create their happy life through hard working.

\subsection{Dress Pattern of Khasia}


The traditional Khasi male dress is a jymphong, a longish sleeveless coat without collar, fastened by thongs in front. Nowadays, most male Khasis have adopted western attire. On ceremonial occasions they appear in a jymphong and sarong with an ornamental waist-band and they may also wear a turban.

The traditional Khasi female dress is called the jainsem or dhara, both of which are rather elaborate with several pieces of cloth, giving the body a cylindrical shape. On ceremonial occasions they may wear a crown of silver or gold. A spike or peak is fixed to the back of the crown, corresponding to the feathers worn by the menfolk. The jainsem consists of two pieces of material fastened at each shoulder. The dhara consists of a single piece of material also fastened at each shoulder.

\subsection{Food Habits}

A Khasi consumes different kinds of food, but rice forms the staple diet. He eats millet, maize, potatoes, yam and tapioca. Among the fruits, jackfruits, pine-apples, pears, fig, oranges and many other local fruits. He also eats cabbage, cauliflower, carrots, turnips, mustard leaves and a variety of wild vegetables, Beef, pork, and chicken is regularly enjoyed. Use of rice-beer is a must in ceremonial and religious occasion.

\subsection{Games and Sports}

Archery, fishing, tied malaishito (a game of hitting a piece of stick) wrestling are some of the traditional games that are played.

\subsection{Festivals}

Dancing and music are important parts of Khasi ritual, and the Nongkrem Dance (part of the pomblangor goat-killing ceremony) is the major festival on the Khasi calendar. It is dedicated to Ka lei Synshar, for the ruling of the Khasi. Its purpose is to ensure substantial crop yield and good fortune for the state. It is held in late spring (usually in May). A number of state and communal rituals are also performed, in addition to many ceremonies associated with the human life cycle (birth, marriage, death, etc.).

\subsection{Arts}

Examples of decorative art include metal gongs (with animal engravings), implements of warfare (arrows, spears, bows, and shields), and memorial slabs (with engravings). To a limited extent woodwork, jewelry, and other industrial manufactures may be so classified. Music is an important part of Khasi religious ceremonies (both communal and clanrelated), hunting expeditions, and athletic events (e.g., archery contests). Musical forms include extemporaneous verse that is said to resemble, in form and content, magicoreligious incantations. Drums, guitars, wooden pipes and flutes, metal cymbals, and various harps are among the instruments used in Khasi musical performance. As was mentioned previously, dancing also accompanies most ceremonies in public and private life. With regard to literature, a considerable body of oral and written material exists. This includes proverbs, myths, legends, folktales, songs, and agricultural sayings.

\subsection{Housing Pattern of Khasia}

The typical Khasi house is a shell-shaped building with three rooms: the shynghup is a porch for storage; the nengpei is the center room for cooking and sitting; and the rumpei is the inner room for sleeping. The homes of wealthy Khasi are more modern, having iron roofs, chimneys, glass windows, and doors.

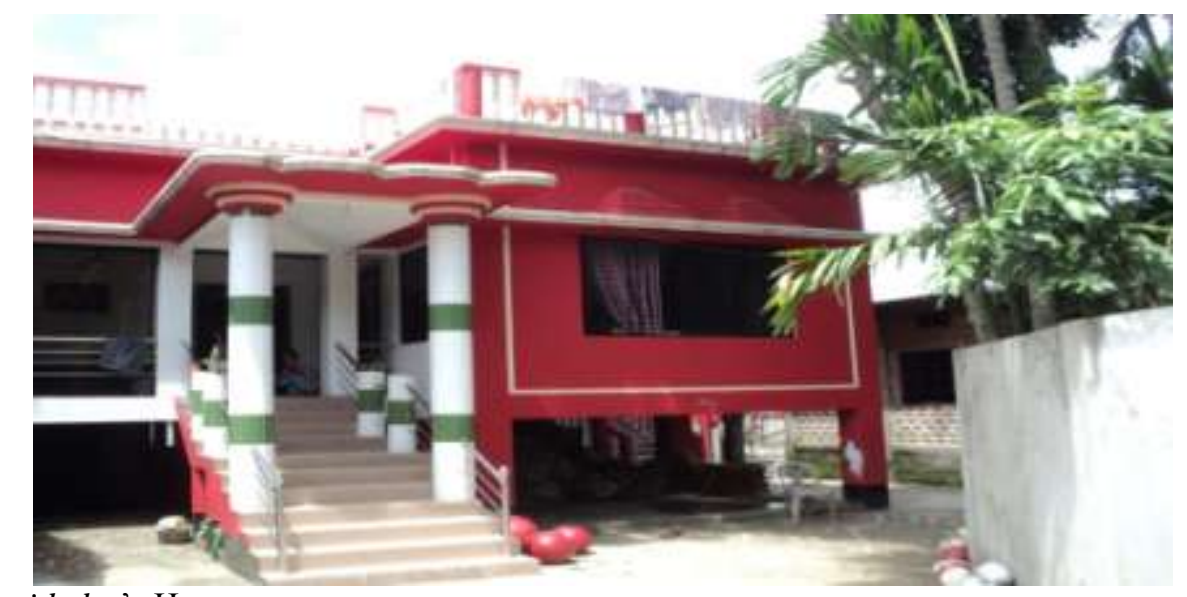

Pic:KhasiaJamidndar's House.

Within Khasi villages one may find a number of public buildings, Christian churches, and schools. 


\subsection{Religious Beliefs}

Christian missionary work among the Khasi began in the late nineteenth century with the efforts of the Welsh Calvinistic Methodist mission. The effects of their endeavors and those of other Christian bodies have been considerable. Today over half of all Khasis have adopted Christianity. The missionary impact may be noted on almost all levels of culture. However, the core of traditional Khasi religious beliefs remains intact. The Khasi believe in a creator god (U BleiNong-thaw) who is considered feminine in gender (Ka lei Synshar). She is invoked when sacrifices are offered and during times of trouble. The propitiation of good and evil spirits is also part of this system, as is the worship of ancestors. The following major spirits are worshiped: UleiMuluk (god of the state); UleiUmtang (god of drinking water and cooking water); UleiLongspah (god of wealth); and $O$ Ryngkew or U BasaShnong (tutelary deity of the village).

\subsection{Death and Afterlife}

In Khasi eschatology, those who die and have proper funeral ceremonies performed on their behalf go to the house (or garden) of God, which is filled with betel-palm groves. Here they enjoy a state of endless bliss. Those who do not receive proper burial are believed to roam the Earth in the form of animals, birds, and insects. This idea of soul transmigration is believed to have been borrowed from Hindu theology. Unlike Christian eschatology, that of the Khasi is not characterized by a belief in any form of eternal punishment after death.

\subsection{Social structure}

The Khasis have a matrilineal and matrilocal society. Descent is traced through the mother, children taking their mother's surname, with maternal uncles traditionally playing a major role in the family, while the father keeps an important role in the household. According to Khasi laws, a woman cannot be forced into marriage, she owns the children and properties. In Khasi tradition, the youngest daughter, the khaduh, will also inherit the property as custodian for her lineage. A woman may end a marriage at her will with no objection from her husband.

\subsection{Woman Right among Khasia}

Khasi women enjoy a high social status and play a significant role in socio-economic matters and household management. Many Khasi women have taken up professions in civil services and in industries besides agriculture.

\subsection{Khasi Polity}

Khasi democracy has been in existence from time immemorial and the system is still followed. A group of small localities are called 'Shnong' where there is a RangbahShnong (village elder) - The groups of Shnongs, constitute a 'Hima' or 'raij' headed either by a Lyngdohor Syiem (chiefs of Hima). The Syiem or Lyngdoh are titular heads and they have no authority to exercise powers at their levels but only through the Dorbar(General council) and this Dorbaris the supreme authority. The Hima deals with land ownership, land revenue, markets and settlement of disputes etc.

In the HimaMawphlang, the Chief is the Lyngdoh who is elected/ nominated from the Lyngdoh clan. There are four myntries (Ministers) nominated from each of the following clans.

(1) Iangblah clan,

(2) Kharshiing clan

(3) Sohliya clan

(4) Kharhunai clan.

The Executive Dorbarconsists of the Lyngdoh, the four myntris and the village elders. The Lyngdohmay summon the Dorbar when he thinks it fit and necessary to settle issues by the DorbarShnong, or Executive Dorbar. The Dorbar has the power to remove the Lyngdoh or Myntriif such incumbents do not conform to its will, traditional customs and usages of the Dorbar. In absence of the Lyngdoh due to death, removal or absence from the Hima, the usual procedure is to allow the Myntrifrom the Iangblah clan to perform his duties as Acting Chief.

The Shnong (village) elects their own RangbahShnong(village elder) from amongst the prominent men of their choice and his name is sent to the Lyngdoh for approval and a sanadissued. He is responsible for maintenance of law and order, settlement of petty cases, sees to the matters of sanitation, civil and other allied matters. The RangbahShnonghas a council of other members of the shnong where from time to time a Dorbarshnongis summoned to settle major issues. The Dorbarby its inherent power may remove any RangbahShnong if the Dorbar finds that such a RangbahShnong has not confirmed to these duties as such, and has violated traditional rule of law.

3.24 Major problems of Khasia people 
The Bangladesh Constitution states that all Bangladeshis are equal citizens, but fails to make any provision for those who see themselves as a citizen of Bangladesh and an indigenous person. Consequently the Government doesn't always acknowledge certain exceptional problems faced by indigenous communities, and as a result, their socio-economic situation is worsening day by day.

- Education is low among ethnic groups. This is particularly evident in the Khasi community where education of children rarely progresses past primary level. The cause of these problems can be attributed partly to the remoteness of ethnic community villages; there are no secondary schools located nearby. Language also creates a problem as many lessons are conducted in Bangla and not the mother language.

- There is very little awareness about the threat of HIV/AIDS within ethnic communities, and the general education rate is very low which limits the understanding on HIV/AIDS and connected issues.

- Employment problems are prevalent throughout indigenous communities. These problems are a product of the isolation of their communities and an unwillingness to integrate into mainstream society.

- Land issues pose a huge threat to the livelihood and future of all indigenous communities in greater Sylhet region. The communities lack official documents which certify ownership of their land and therefore have no legal support for their land.

- Remote locations of villages mean that medical facilities are far and very difficult to access. There are Case-1 generally no people with formal medical training in the villages.

Name: Agnes Dikhar

Age: 26

Marital Status: Unmarried.

Village:SongramPunji.

Agnes Dikhar is a 26 years aged unmarried Kashia woman and lives with others three members including one brother 17 years, father and mother. She is a member of nuclear family. Her forefathers flowed Hindu religious but at that time her family members are flowing Christian religion. Because of the activeness of Christian Missionary they are converted Hindu to Christian. She lives in Khacahouse locally named Chang Gor. It hasthree rooms and a veranda with electricity facility. She converted to Christian. For this reason she is getting various social and financial supports from Christian Missionary. For that reason she decides to make a building instate of Chang Gor. She said that they use Kashia language as their first language to communicate with others verbally because it has no written document. They use Bangla as their second language. Their medium of education is also Bangla. After completing her primary education she enrolled in class six and read up to class ten. Due to financial problems she dropped out.

Kashia communities are matriarchy. For this reason her mother is the head of her family. But in decision making both mother and father have the power to make any decision .Now-a-days male gets more power to take any social and economical decision.

Monogamy marriage system is strictly flowed in kashia community. According to the tradition, the groom has to live in the bride's house after getting married, but now fewer men does so. Consuming right of the land and others properties belonged mother to daughter. The ownership of the land is the Jaminder or head man. They have no legal private property. They can only use or consume their land but can't sell and buy. But they have to pay Tax to their Jaminder.

Agnes Dikharmentioned that they still use the traditional method in cultivating their lands. They still depend on bullock, bill-hook, spade buckets, plough, and so on hand made tools for cultivation. Betel leaf cultivation is the main occupation of Agnes Dikhar .Besides that she also produced betel nut and small number of paddy on plain land. Basically they produce goods for their own uses but they also sale their surplus production to market.

Due to adopting Christian religion, various cultural changes are appearing in their culture. They are celebrating various religion practices as like Christmas day, Star Sunday, and Star Monday. Rice is their Staple food but in those special days they eat various cakes, sweets and swine meat. They take food three times in a day like other Bangladeshi.Generally, Male wears Lungi, napkin, shirt and pants. On the other hand female wears Dia king, Dharaand so on but in various social and religious occasions they wear costly dress named khatokkarcha. She argued that the health condition of the people living in this area is not satisfactory. There is no hospital and M.B.B.S doctor in their communities. For this reason they have to go village doctor and local pharmacy for treatment. On the other hand there is no single secondary school and collage near by their community.

Every decision regarding their community taken by their head man as well as Murabbibut head man's decision is the last decision.Head man does not create any presser to his community member for voting at this reason Agnes Dikhar can vote for her choosing person.Because of rising social awareness, now-a-days they take any decision by both male and female's mutual understanding basis. On the other hand after marriage, male reside with female's house this tradition breaking down gradually at their community. 
She is getting various social and economical supports from Christian missionary and small number of GOs and NGOs relief.

Case-2

Profiles of the OmoniDikhar

Location:SongramPunji.Goaingat, Sylhet

This case study was conducted on OmoniDikhar, a female who is about 50 years old and used to live with her

\begin{tabular}{|l|l|l|l|l|l|l|l|}
\hline Name & Age & Sex & $\begin{array}{l}\text { Marital } \\
\text { Status }\end{array}$ & $\begin{array}{l}\text { Educational } \\
\text { Status }\end{array}$ & Occupation & $\begin{array}{l}\text { Income } \\
\text { (Monthly) }\end{array}$ \\
\hline Self & OmoniDikhar & 50 & Female & widowed & Illiterate & $\begin{array}{l}\text { Betel Leaf } \\
\text { Processing }\end{array}$ & --- \\
\hline $\begin{array}{l}\text { Son-in- } \\
\text { law }\end{array}$ & GynamSorenKongstia & 32 & Male & Married & $\begin{array}{l}\text { Up to class } \\
\text { five }\end{array}$ & $\begin{array}{l}\text { Betel Leaf } \\
\text { Cultivation }\end{array}$ & 7000 TK \\
\hline Daughter & BalariDikhar & 27 & Female & Married & $\begin{array}{l}\text { Can sign } \\
\text { only }\end{array}$ & $\begin{array}{l}\text { Betel Leaf } \\
\text { Cultivation } \\
\text { Processing }\end{array}$ & -- \\
\hline
\end{tabular}

other 2 family members including son, and daughter-in-law.

OmoniDikhar said that they use Khasia language as their first language to communicate with others verbally, because it has no written document. They use Bangla as their second language. Their medium of education is also Bangla. She can't sign his name. She said poverty was the main constraint of his education. Besides her parents never encouraged her to go to school, and she was involved in agricultural activities with her mother. She got married at 14 ages and took one child and she became widow at about 26 years old age. Her forefathers flowed Hindu religious but at that time her family members are flowing Christian religion. She mentioned that she has no land of her own. The ownership of the land is the Jaminder or head man. They have no legal private property. They can only use or consume their land but can't sell and buy. But they have to pay Tax to their Jaminder. She also mentioned that they still use the traditional method in cultivating their lands. They still depend on bullock, bill-hook, spade, buckets, plough for cultivating their lands. Theyproduce rice, paddy fruits as the main crops. Basically they produce goods for their own uses. They sale their surplus production to market.

She argued that the health condition of the people living in this area is not satisfactory. Particularly women and children are more vulnerable than male. Women did not get sufficient facilities of treatment and the housing condition is not well supported. There is no hospital and M.B.B.S doctor in their communities. For this reason they have to go village doctor and local pharmacy for treatment. On the other hand there is no single secondary school and collage near by their community.

Monogamy marriage system is strictly flowed in kashia community and after marriage male has to comebride' s house. She also said that female member is the head of the family. Most of the families are nuclear. In selection of their life partners they have to follow the endogamous rule. Their families are monogamy and they are matrilocal. There is no scope of dowry or mohor or any other give and take system in their marriages.

OmoniDikhar said that the overall education system of his area is not good. There are only two primary schools in her village. But there is no Secondary school and college in her community. Bangla is used as the medium of education.

Khasia people have their own traditional cultural values which is different from the mainstream people. Khasia male members wear lungi and and shirt. And in special days they wear shirt and pant. And the female members wear sari, Dia king, Dharaand so on but in various social and religious occasions they wear costly dress named khatokkarcha.

Due to adopting Christian religion, various cultural changes are appearing in their culture. They are celebrating various religion practices as like Christmas day, Star Sunday, and Star Monday. Rice is their Staple food but in those special days they eat various cakes, sweets and swine meat. They take food three times in a day like other Bangladeshi.Every decision regarding their community taken by their head man as well as Murabbibut head man's decision is the last decision. Head man does not create any presser to his community member for voting at this reason OmoniDikhar can vote for her choosing person.

Because of rising social awareness, now-a-days they take any decision by both male and female's mutual understanding basis. On the other hand after marriage, male reside with female's house this tradition breaking down gradually at their community. She is getting various social and economical supports from Christian missionary and small number of GOs and NGOs relief.

\section{Case-3}


Name: Tokas

Age: 22

Marital Status: Married.

Village:SongramPunji.

Tokasis a Khasiamaleliving with other 12 members in a joint family.He has been living at SongramPunji since his birth.his forefathers came hare about 30-40 years ago.He is a 22 years aged young Khasia male. He can read and write only. He got married at 22 years age with a 20 year age Khasia woman. He has a daughter. His forefathers flowed Hindu religious but at that time her family members are flowing Christian religion. Because of the activeness of Christian Missionary they are converted Hindu to Christian.

Tokas said that they use Khasia language as their first language to communicate with others verbally, because it has no written document. They use Bangla as their second language. Their medium of education is also Bangla. He can read and write only. He said poverty was the main causes of his drop out from school.

The ownership of the land is the Jaminder or head man. They have no legal private property. They can only use or consume their land but can't sell and buy. But they have to pay Tax to their Jaminder. After marriage male has to come his mother- in-low's house. He also said that female member is the head of the family. In selection of their life partners they have to follow the endogamous rule. Their families are monogamy and they are matrilocal. There is no scope of dowry or mohor or any other give and take system in their marriages.

Tokas mentioned that they still use the traditional method in cultivating their lands. They still depend on bullock, bill-hook, spade, buckets, plough for cultivating their lands. They produce rice, paddy fruits as the main crops. Basically they produce goods for their own uses and sale surplus production to market.

There is no hospital and M.B.B.S doctor in tokas community. For this reason they have to go village doctor and local pharmacy for all treatment. Particularly women and children are more vulnerable than male. Women did not get sufficient facilities of treatment and the housing condition is not well supported. On the other hand there is no single secondary school and collage near by their community.

There are only two primary schools in her village. But there is no Secondary school and college in her community.Tokassaid that the overall education system of his area is not good because of using Bangla as the medium of education.

Khasia male members wear lungi and and shirt. And in special days they wear shirt and pant. And the female members wear sari, Dia king, Dharaand so on but in various social and religious occasions they wear costly dress named khatokkarcha. He mentionedKhasia people have their own traditional cultural values which is different from the mainstream people.

Various cultural changes are appearing in their culture. Due to adopting Christian religion, they are celebrating various religion practices as like Christmas day, Star Sunday, and Star Monday. Rice is their Staple food but in those special days they eat various cakes, sweets and swine meat. They take food three times in a day like other Bangladeshi.Every single decision regarding their community taken by their head man as well as Murabbibut head man's decision is the last decision. Head man does not create any presser to his community member for voting at this reason tokascan vote for her choosing person.After marriage, male reside with female's house this tradition breaking down gradually at their community. Because of rising social awareness, now-a-days they take any decision by both male and female's mutual understanding basis. Various NGOs, especially BRAC play significant role to solve his minorities or others problems. He got governmental relief several times but it was very small amount. On the other hand he is getting social and economical supports from Christian missionary

\section{Key Finding}

\section{Discussion}

From the case studies we can observe some common and influential aspects of Khasia people and their livelihood. We can see that their culture and livelihood pattern is different from the mainstream people of the society from different aspects.

The Khasia people are traditionally involved in agricultural activities. It is their ascribed occupation. They still are using the traditional method in cultivating their lands. They depend on bullock, bill-hook, spade buckets, plough, and so on hand made tools for cultivation. Betel leaf cultivation is the main occupation of Khasia. Besides that they also produced betel nut and small number of paddy on plain land. Basically they produce goods for their own uses but they also sale their surplus production to market.

From the case studies we can find the Khasia communities flowed Hindu religious but at that time most of the Khasi are flowing Christian religion. Because of the activeness of Christian Missionary they are converted Hindu to Christian. 
The typical Khasi house is a shell-shaped building with three rooms: the shynghup is a porch for storage; the nengpei is the center room for cooking and sitting; and the rumpei is the inner room for sleeping. The homes of wealthy Khasi are more modern, having iron roofs, chimneys, glass windows, and doors. Within Khasipunji we found a number of public buildings, Christian churches, and schools.

Monogamy marriage system is strictly flowed in kashia community. According to the tradition, the groom has to live in the mother-in-law's house after getting married, but now fewer men does so. Consuming right of the land and others properties belonged mother to daughter. In selection of their life partners they have to follow the endogamous rule. Their families are monogamy and they are matrilocal. There is no scope of dowry or mohor or any other give and take system in their marriages.

In the Khasia community there also exist some other problems like Education is low among Khasi community where education of children rarely progresses past primary level. There are no secondary schools located nearby. Language also creates a problem as many lessons are conducted in Bangla and not the mother language. There is very little awareness about the family planning within Khasia communities; Employment problems are prevalent throughout indigenous communities. These problems are a product of the isolation of their communities and an unwillingness to integrate into mainstream society. The communities lack official documents which certify ownership of their land and therefore have no legal support for their land. On the other hand remote locations of village means that medical facilities are far and very difficult to access. There are generally no people with formal medical training in the villages. Consequently typical diseases with symptoms such as diarrhea, fever, and reproductive health problems are highly prevalent, and in Khasi hilly areas, malaria is also present. GOs and NGOs should take necessary steps to alleviate these problems of Khasia people.

We found some essential information. In the following the analysis are given briefly:

- The socio economic condition of Khasia people is not so good.

- They are mainly involved with agricultural activities specially betel leaf cultivation.

- Khasia people have their own traditional cultural and religious beliefs.

- They can enjoy all their religious and traditional customs and festivals freely.

- There is very little awareness about the family planning within Khasia communities

- In Khasia communities the status of women is quite good.

- They have a little access to land right.

- Most of the Khasia people are illiterate. Language also creates a problem as many lessons are conducted in Bangla and not the mother language.

- Their overall health condition is not satisfactory.

- They have the rights to take participation in electing local and national govt.

\section{Policy recommendations}

\section{Recommendation And Conclusion}

Where there is a difficulty there is a way. There are also some ways by which the problems of Santa people may be reduced .Those are given below

$\rightarrow$ Necessity of education should be understandable to the Khasia people.

$\Leftrightarrow$ Number of educational institutions must be established.

$\Leftrightarrow$ They should provide proper health care facilities.

$\Leftrightarrow$ Government should give proper credit facilities to the Khasia farmers.

$\Leftrightarrow$ Khasia communities should be given proper rights.

$\Leftrightarrow$ Government should take proper steps so that the Khasia people can enjoy the rights of land ownership.

$\Leftrightarrow$ They should be encouraged to use modern methods of cultivation.

$\Leftrightarrow$ NGOs should be more active to help the Khasia indigenous people.

$\Leftrightarrow$ The infrastructure of this area should be developed.

$\stackrel{4}{4}$ Access to bank loan.

\section{Conclusion}

The Khasi are an endogamous tribe who are divided into exogamous clans which are again subdivided into exogamous matrilocal families. The exogamous clans are Lyngoh, Kharkongor, Diengdoh, Sohkhler, Marbaniang and syiemlich who trace their descent from respective female ancestress. Inter marriage between them is allowed. There are no child marriages. Marriage has both a religious and a social aspect among the Khasi tribes. Monogamy is the common form of marriage. Polygamy and polyandry are not known among them. As their society is matriarchal all the earning of males and females are owned jointly and administered by the head woman. Property is inherited from mother to daughter. Khasi family life is woven into religious rituals and ceremonies. In some cases it has seen that women act as religious and secular chiefs. Most of the Khasia people are involved in agricultural activities. But it is a matter of great sorrow that Bangladesh govt.is ignoring them. 
Govt. assistance regarding their socio-economic development is very poor. Some NGOs are trying to improve their condition but it is insufficient. Govt. should take necessary steps to alleviate their problems.

\section{References}

[1] Banglapedia National Encyclopedia Bangladesh, 2011, Access on September26, 2012. Retrieved from [ http://www.banglapedia.org/httpdocs/HT/G_0144.HTM]

[2] Brach. H. (1974). Magalia, North-Eastern India News and Feature service, Shilling, India.

[3] Chowdhury, J.N (1998), TheKhasi Canvas, KaIbadasuk Book Agency, Shillong, India.

[4] Chowdhury, J.N.(1984). The Khasis: Conjectures about their Origin.inKarotemprel,Shillong, India.

[5] Dutta, P.N. 1982. Impact of the West on Khasi and Jaintias (A survey of political, economic and social change), Cosmo Publications, New Delhi, India.

[6] Field work \& interview with Khasia

[7] Gurdon, P.R. 1996. The Khasis, Low Price Publication, New Delhi, India

[8] Jary, D. and Jary. J. 2000. Collins Dictionary of Sociology ( $3^{\text {rd }}$ edition). Harper Collins Publishers, Glasgow

[9] Munda, R.D. 2002. India's Protection and Promotion of Tribal Rights: Obligation under ILO convention on Indigenous and Tribal peoples, 1957 (No. 107), Paper presented at Indigenous Rights in the Commonwealth Project South and South-East Asia Regional Expert Meeting, New Delhi, India.

[10] Rahman, M. (2004). Combating the Khasi Uprooting: Humanity Cries, Empowerment through Law of the Common People (ELCOP), Dhaka, Bangladesh.

[11] Risley, H. H. 1891The Tribes and Castes of Bengal, Calcutta, p. 232

[12] Wikipedia, the free encyclopedia, 2012, Access on September 14, 2012 Retrieved from [http//www.wikipedia.orgwikiKhasia.]

\section{Appendix-1}

\section{A Checklist \\ On}

The Socio-Economic Background of Khasia Ethnic Community of Bangladesh

Date $-\ldots . \ldots / \ldots / \ldots \ldots /$

List No -

\section{Socio-economic and Demographic Information:}

1. Name of the Respondent:

2. Age (Respondent):

3. Sex (Respondent):
I. Male
II. Female

4. Educational qualification:
I. Illiterate, II. Can read and write only
III. Six to ten
IV. Can sign only, V. Up to class five,
VI. Above ten
VII. Up to H.S.C VIII. B.S.S/M.Sc/M.com
IX. M.S.S / M.Sc / M.com

5. Marital status:
II. Unmarried
III. Divorced
IV. Widowed

6. Age at marriage:

Male.

7. Head of your family:
I. Husband/father
III. Wife/mother III. Community leader

IV. Other.. (Specify)

8. Family type:

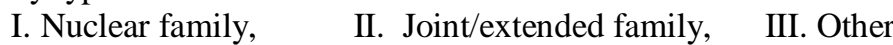

9. Number of family members: Male: Female:

10. Total number of family members:

11. Do you have any children? I. Yes II. No

12. If yes, how many children:

13. Religion:
I. Islam
II. Hindu
III. Christian
IV Other (Specify)

Major concerns in minorities and indigenous studies

14. From when you live here?

15. From which you came here......................(place)

16. Causes of came this place:....

17. In which language do you speak?

18. Origin of your language.

19. Pattern of dress (a) Male.

(b) Female.

20. Are practice dowries in the marriage time? 1) Yes 2) No 
21. If yes, then which elements are given as dowry?

22. After marriage do the girls where living.....

23. Are practicing divorces, in your community? 1) Yes

2) No

24. If yes, then which process is maintained in divorces time? 1) Legal 2) Traditional 3) Others (please specify).

25. Your children easily go to school....

26. Education facilities are found your community. 1) Yes 2) No

27. If yes, then have you found other education allows?

28. If no, then the causes.

29. Do you face any other problem in education? 1) Yes 2) No

30. If yes, then which types of inequalities? 1) Drop out of children 2) inequality

3) Untouchability 4) Others (please specify)

31. Have you are getting proper health facilities:1) Yes 2) No

32. If no, health problem type are:

33. Toilet condition: 1) Sanitary

34. Main sources of drinking water:

2) Structured

3) Unstructured

4) Others

35. Permanent land access: 1) Yes

1) Tube well

2) Filtered

3) Pond

4) Others

36. If no, then who is the owner of this land?

37. Other natural resources access:

1) Yes

2) $\mathrm{No}$

\section{Property Right and Land Ownership}

38. Do you have any permanent property?

39. Yes II. No

40. Mention the types of property

41. Who is the owner of the land?
I. Male
II. Female

42. Do you have any legal document of land ownership?

43. Do you have the rights of selling/buying land?

44. Pattern of property distribution among the siblings.

45. Do you give any tax?

\section{Information about cultivation system}

46. Do you have had any interest on cultivation system?

47. Yes II. No

48. If yes, mention the types of your cultivation system:

49. Mostly using instruments in cultivation:

50. Type of land used for cultivation:
I. Plain land
II. Hill track

51. For whom you produce crops?

52. Which crops grow much?
I. Own self
II. Selling

\section{Situation of religious minorities}

53. Religious right access: 1) Yes 2) No

54. Is there any religious leader,1) Yes 2) No

55. Religious festivals type.

56. Have any problem in celebrating religious festivals? 1) Yes 2) No

57. If yes, which group creates pressure?

58. Pressure type:

\section{Socio-Economic Status of Women}

59. Have you opportunity in participation on decision making? 1) Yes 2 2) No

60. Have you opportunity in movement anywhere easily? 1)Yes 2)No

61. If No, why. 
62. Are you financially depending on your husband/son? 1)Yes 2)No

63. If no, Who support you?...

64. Are you facing inequality? 1)Yes 2)No

65. If yes, which cause.

66. Have you easily play religious activities.1)Yes 2)No

67. If no, cause.

68. How much you get property right......

69. Is maternal care available here? 1) Yes 2 2) No

70. If no, cause

\section{Development intervention}

71. Have modernization project/policy taken here?

72. If yes which type?

73. If yes any problems are, creates for this project?

74. Are getting credit access?1) Yes 2) No

75. If no, why

76. Have any Organizational role to solve your minorities or others problems?

1) Yes No

77. If yes, then, which Organization?
78. Mention
any
other
problem
do
you
face
to live

79. Which way do you solve the problem.

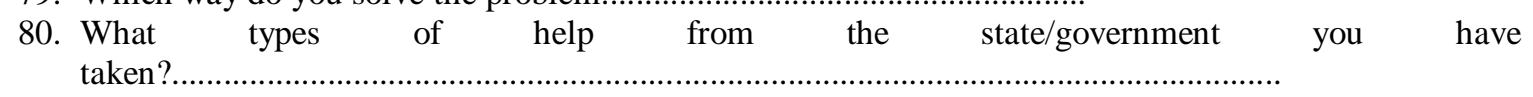

Name of the interviewer

Date

Thanks for your cooperation

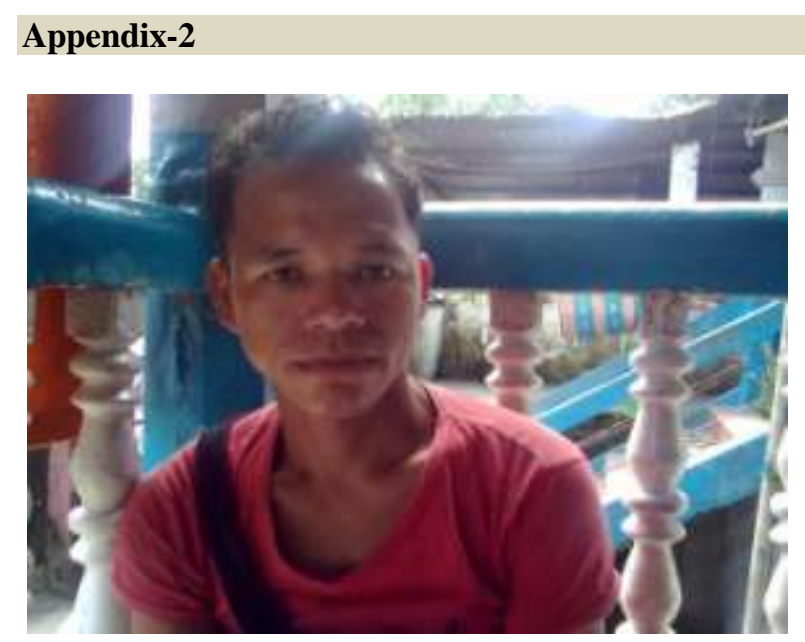

Tokas AKhasia young manHouse of Khasia
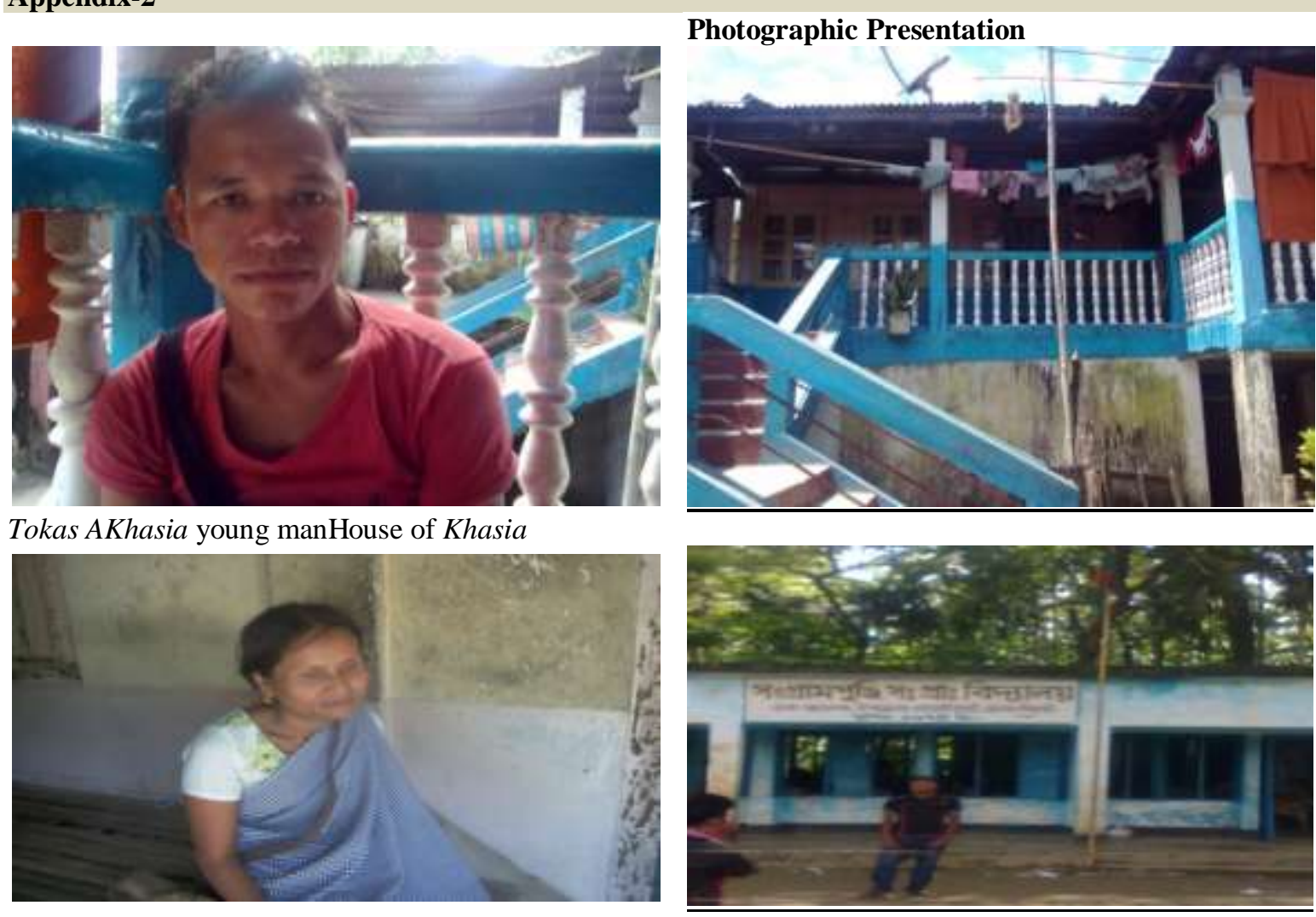

Khasia woman

Primary School ofSangranPunji 